\title{
1 Effects of cork oak stripping on tree carbon and water fluxes
}

2

3 Costa-e-Silva, F. ${ }^{a}{ }^{*}$, Correia, A. C. ${ }^{a}$, Pinto, C. A. ${ }^{\text {ba }}$, David. J. S. ${ }^{\text {a }}$, Hernandez-Santana, V. ${ }^{\text {, }}$

4 David, T. S. ${ }^{\text {b,a }}$

5

7

8

9

${ }^{a}$ Centro de Estudos Florestais, Instituto Superior de Agronomia, Universidade de Lisboa, Tapada da Ajuda, 1349017 Lisboa, Portugal.

b Instituto Nacional de Investigação Agrária e Veterinária, I. P., Av. da República, Quinta do Marquês, 2780-157 Oeiras, Portugal.

c Instituto de Recursos Naturales y Agrobiología de Sevilla (IRNAS), Av de la Reina Mercedes, 10, 41012 Sevilla, Spain.

*corresponding author

E-mail adresses: filipecs@isa.ulisboa.pt (F. Costa-e-Silva), alexandrac@isa.ulisboa.pt (A. C. Correia), clara.pinto@iniav.pt (C. A. Pinto), soaresdavid@isa.ulisboa.pt (J. S. David), virginiahsa@gmail.com (V. Hernandez-Santana), teresa.david@iniav.pt (T. S. David).

\section{Abstract}

Cork is a high value periodical forest product which ensures the economic, social and ecological sustainability of cork oak woodlands. Abiotic and biotic stresses lead to tree decline which is endangering the productivity and sustainability of these ecosystems. It is therefore critical to find and implement management practices that minimize the impact of these stresses. The current study was conducted in a certified evergreen cork oak woodland of central Portugal under Mediterranean climate. The main aims of the study were to assess the effects of cork stripping in tree water and carbon fluxes. Results are based on the monitoring of cork stripped and unstripped (control) trees. The experiment was repeated with different sets of trees during 
two contrasting summers (2014 and 2015). 2014 was a wet year (924 mm) with a typical summer drought pattern and 2015 a dry year $(440 \mathrm{~mm})$ with a $31 \%$ reduction in annual average precipitation. In 2015 the experimental site was entirely cork harvested and effects on ecosystem $\mathrm{CO}_{2}$ fluxes were evaluated. Results showed that the amount of carbon in harvested cork represents less than $1.5 \%$ of net primary production on a yearly basis. In addition, cork tissue is very low demanding in nutrients: primary macronutrients content in cork represents approximately $2 \%$ of the yearly nutrient needs of leaf canopy. Regardless of the climatic year, trunk water losses following cork stripping amounted to only $2 \%$ of canopy transpiration not affecting significantly summer tree water balance. However, cork stripping induced a $46 \%$ decrease on sap flow in the dry year suggesting that cork stripping triggered an increase in stomatal closure through an interaction between stripping traumatic effects and soil water scarcity. Although the effects of summer drought on carbon sequestration are more prominent than cork stripping effects, this superimposed stress led to a significant reduction of summer net carbon ecosystem exchange ( $c$. $32 \%$ ). Our results suggest that cork stripping detrimental effects can be especially critical in more vulnerable trees growing near their vitality breakdown threshold. Therefore, and concerning cork oak woodland management, the cork stripping practice should be avoided in severe dry years and in the more stress-prone trees.

Key-words: Quercus suber L., cork harvesting, summer drought, water stress, sap flow, Mediterranean ecosystem

\section{Introduction}

Cork oak (Quercus suber L.) open woodlands cover an area of about 2-2.5 million ha in the western Mediterranean Basin. The largest areas are located in Portugal (0.74 million ha) and Spain (0.6 million ha), corresponding to more than $50 \%$ of its world distribution area (Aronson 
et al., 2009). Cork is a high value renewable forest product, which ensures the economic, social and ecological sustainability of cork oak woodlands (Bugalho et al., 2011). Portuguese cork provides $0.7 \%$ of the gross domestic product, with cork wine bottle stoppers the most valuable derived product, and amounts to 54\% of the worldwide cork production (Evangelista, 2010). Cork oak bark is produced by the phellogen (cork cambium), a secondary meristem that maintains its activity throughout the tree life and forms successive annual cork layers. Cork stripping is done traditionally every 9 years to obtain commercial grade cork. It is removed for the first time when the tree is $18-25$ years old and thereafter successively every 9 years during the tree lifespan $(150-200$ years). After cork stripping the phellogen dies and a new one is formed almost immediately ( 25 - 35 days). Cork stripping is a delicate manual process, requiring skilled workers to remove cork with an axe without reaching and damaging the vascular cambium below the phellogen (Pereira, 2007). Stem wounds constitute open windows for infection and biological attack, liable to lead to a decline in cork production (Costa et al., 2004) and ultimately to tree death. To prevent these injuries, cork can only be safely removed when the phellogen cells are actively dividing - turgid cells with thin, fragile cell walls - from late-spring to mid-summer. However, in the Mediterranean region this is a period of potential water deficit, with high air evaporative demand and low soil water availability. Under these conditions, cork stripping may be viewed as an additional stress factor due to immediate carbon and water losses that entail changes in photosynthate allocation and in tree water balance. Rough estimates of daily water loss from stripped surfaces suggested that they can equal canopy transpiration (Correia et al., 1992; Oliveira and Costa, 2012).

Tree strategies to compensate for this water loss should lead to a reduction in leaf transpiration either through stomatal closure or leaf area reduction (e.g. leaf shedding). However, in the short-term, the effects of stripping on stomatal conductance $(g s)$ are discordant in literature, ranging from small reductions on $g s$ not limiting photosynthesis (Werner and 
Correia, 1996) to different responses according to trees (Correia et al., 1992). Moreover, tree water status, reflected by leaf water potential, does not seem to change considerably in stripped cork oaks (Correia et al., 1992; Werner and Correia, 1996). On the other hand, effects of cork stripping on tree radial growth seem clear. After stripping, cork growth shows a notable increment in the first year which can reach 2 to 3 times the thickness of previous annual periods (Costa and Oliveira, 2001; Costa et al., 2003). Conversely, radial wood growth exhibits a decrease in the years immediately after cork stripping, even under favourable water availability (Leal et al., 2008). It is conceivable that during the intensive growth flush of cork oak (i.e. late spring) the allocation of recently assimilated carbon and of stored carbon to regenerate the cork layer (Aguado et al., 2012) induces a general reduction in tree growth. Thus, even if it has been observed that cork stripping may induce stress in trees, the nature of this stress remains poorly understood (Oliveira and Costa, 2012).

Cork oak is a well-adapted tree to the adverse Mediterranean hot dry-summer climate, namely limited water availability, high temperatures and high light intensities during summers (Pereira et al., 2009). Successful adaptations range from an efficient root-shoot architecture and water transport processes (David et al., 2007, 2012; Kurz-Besson, 2006) to leaf morphology and physiology (David et al., 2004; Vaz et al., 2010) or phenology (Oliveira et al., 1994; Pinto et al., 2011). Nevertheless, and despite being considered drought resilient, a succession of dry years or severe stress episodes may lead water deficits that reach a breakdown threshold, resulting in tree decline or even mortality. Within the existing trend of tree decline, as a consequence of abiotic and biotic stresses endangering the productivity and sustainability of cork oak woodlands (montados), it is critical to understand how trees cope with cork stripping stress and how long they take to regain carbon and water balance, at tree and ecosystem level. This experimental knowledge is needed to support better management practices and decisions, based on solid predictions of ecosystem responses to abiotic risks. 
Mediterranean climate of central Portugal. The main aims of the study were to assess the effects of cork stripping on: 1) tree water and carbon fluxes response; 2) net carbon ecosystem exchange (NEE). Results are based on the monitoring of two treatments: cork stripped and unstripped control trees. The experiment was repeated during two contrasting summers: 2014, a wet year, and 2015, a dry year. Main measurements comprised: tree water status, integrated branch carbon uptake and trunk gas exchanges. In 2015 the cork oak woodland was cork harvested and effects on ecosystem $\mathrm{CO}_{2}$ fluxes were evaluated.

\section{Material and methods}

\subsection{Site description, vegetation and climate}

The experiment was conducted during summers of 2014 and 2015 in a cork oak open woodland located at Herdade da Machoqueira (3908'18.29’ N, $\left.8^{\circ} 19^{\prime} 57.68^{\prime} \mathrm{W}\right)$ in Central Portugal. The property has 1017 ha of pure cork oak montados, being the average cork production per hectare of $1300 \mathrm{~kg}$ dry weight each 9 years. Vegetation consists of $c a .50$-yr-old cork oak trees with an understory of semi-deciduous shrub species (e.g. Cistus sp., Ulex sp.) and native grassland (Costa-e-Silva et al., 2015). The climate is Mediterranean, with wet, mild winters and dry, hot summers. Average annual rainfall is $638 \pm 66 \mathrm{~mm}$ and mean annual temperature is $15.7 \pm 0.1^{\circ} \mathrm{C}$ (2009-2018, site meteorological data). The soil is a Cambisol (FAO), with $81 \%$ sand, $5 \%$ clay and $14 \%$ silt, with roots mainly in the upper horizons (ca. $0-40-\mathrm{cm}$ depth) with some sinker roots taking water from deeper soil horizons and subsoil. From observations at a nearby borehole the water table level is estimated to vary between 3 and $5 \mathrm{~m}$ depth. Other general site characteristics are described in Table 1 for the studied period. Total precipitation is based on 
125 the hydrological year (October to September) beginning with the usual onset of autumn 126 precipitations.

127 Table 1. Climate in 2014 and 2015, tree and ecosystem characteristics. Values are means $\pm s e$.

\begin{tabular}{lccc}
\hline Characteristic & 2014 & 2015 & Units \\
\hline Climate & 15.4 & 15.8 & $\left({ }^{\circ} \mathrm{C}\right)$ \\
Mean temperature & 12694 & 13520 & $\left(\mathrm{~mol} \mathrm{~m}^{-2}\right)$ \\
$\begin{array}{l}P A R \\
\text { Total precipitation }{ }^{\text {a }}\end{array}$ & 924 & 440 & $(\mathrm{~mm})$ \\
Seasonal precipitation $^{\text {b }}$ & & & \\
$\quad$ Autumn (Oct-Dec) & 333 & 285 & $(\mathrm{~mm})$ \\
$\quad$ Winter (Jan-Mar) & 288 & 86 & $(\mathrm{~mm})$ \\
$\quad$ Spring (April-June) & 147 & 54 & $(\mathrm{~mm})$ \\
$\quad$ Summer (Jul-Sept) & 156 & 15 & $(\mathrm{~mm})$
\end{tabular}

Vegetation

Maximum leaf area index

2.1

1.8

Density

177

$\left(\right.$ trees $\left.\mathrm{ha}^{-1}\right)$

Crown cover

56.4

Height

$9.5 \pm 0.5$

(m)

Diameter at breast height

$29.4 \pm 1.4$

(cm)

Ecosystem

$\begin{array}{lccc}\text { Net ecosystem exchange } & -381 & -256 & \left(\mathrm{~g} \mathrm{C} \mathrm{m}^{-2} \text { year }^{-1}\right) \\ \text { Gross primary productivity } & 1527 & 949 & \left(\mathrm{~g} \mathrm{C} \mathrm{m}^{-2} \mathrm{year}^{-1}\right) \\ \text { Total ecosystem respiration } & 1147 & 693 & \left(\mathrm{~g} \mathrm{C} \mathrm{m}^{-2} \mathrm{year}^{-1}\right) \\ \text { Net primary productivity (trees) } & 887 & 558 & \left(\mathrm{~g} \mathrm{C} \mathrm{m}^{-2} \text { year }^{-1}\right)\end{array}$


${ }^{\mathrm{a}}$ hydrological year; ${ }^{\mathrm{b}}$ Considering 3-month sums; ${ }^{\mathrm{c}}$ Yearly carbon fraction removed in cork biomass (considering $1300 \mathrm{~kg}$ of cork in each 9-years harvesting and 57\% of carbon content in cork according to Gil et al., 2005)

\subsection{Tree sampling}

Following a survey of stand mean tree diameter, crown projected area and tree height, a sample of 12 trees per year was selected in 2014 and 2015, all in the same exploitation stage having reproduction cork (from the third harvesting onwards). All trees were selected within a representative plot of 40-m radius. In each year we separated the 12 selected trees in two similar pairwise sets of cork stripped and unstripped control trees to be monitored throughout the summer. Cork stripping of the 6 trees was done in July 7 (2014) and in June 30 (2015). In 2015, from June 11 to 13 , all trees in the cork oak woodland were cork harvested (except the 12 treatment trees). Current legislation regulates maximum stripping height through the cork harvesting coefficient (HC): ratio between stripping height and trunk perimeter at $1.30 \mathrm{~m}$ above the ground $(\mathrm{PBH})$. This index determines maximum values according to the tree exploitation stage, e.g. in the case of reproduction cork maximum stripping height can not exceed three times PBH (Oliveira and Costa, 2012). General tree morphological traits per treatment and year are presented in Table 2.

Table 2. General tree morphological traits per treatment (control and cork stripped trees) in 2014 and 2015. Values are means $\pm s e(n=6)$.

\begin{tabular}{lcccc}
\hline & \multicolumn{2}{c}{2014} & \multicolumn{2}{c}{2015} \\
\hline & Control & Stripped & Control & Stripped \\
& & & & \\
\hline Height $(\mathrm{m})$ & $11.4 \pm 0.7$ & $9.6 \pm 0.5$ & $9.8 \pm 0.3$ & $11.3 \pm 0.4$
\end{tabular}




$\begin{array}{lcccc}\text { Diameter at breast height }(\mathrm{cm})^{\text {a }} & 30.0 \pm 2.2 & 31.1 \pm 2.5 & 27.1 \pm 1.3 & 27.0 \pm 1.5 \\ \text { Crown projected area }\left(\mathrm{m}^{2}\right) & 42.2 \pm 6.5 & 42.1 \pm 9.1 & 40.0 \pm 9.0 & 44.0 \pm 7.0 \\ \text { Harvesting coefficient }-\mathrm{HC}^{\mathrm{b}} & - & 2.1 \pm 0.2 & - & 2.6 \pm 0.2 \\ \text { Cork stripping surface area }\left(\mathrm{m}^{2}\right) & - & 2.6 \pm 0.5 & - & 2.2 \pm 0.2\end{array}$

${ }^{\mathrm{a}}$ diameter measured under cork; ${ }^{\mathrm{b}}$ stripping height to $\mathrm{PBH}$ ratio

\subsection{Meteorological data}

The following meteorological data were collected at the experimental site: rainfall (ARG100;

Environmental Measurements Ltd., Gateshead, UK), photosynthetically active radiation (PAR) (BF2; Delta-T Devices Ltd., Cambridge, UK), air humidity and temperature (CS215; Campbell Scientific, Inc., Logan, UT, US). Values were recorded continuously in 30-min time intervals (CR10X; Campbell Scientific, Inc., Logan, UT, US). Soil volumetric water content was measured up to 40-cm depth $(2,10$ and $40 \mathrm{~cm})$ with dielectric soil moisture sensors in two different places (EC5; Decagon Devices, Inc., Pullman, WA, US). These measurements were automatically recorded in a datalogger (Em50; Decagon Devices, Inc., Pullman, WA, US) as 30-min averages.

\subsection{Litter fall and cork nutrient content}

Litter fall was collected in 16 litter traps of $0.5 \mathrm{~m}^{2}$ placed in two transects across the footprint area of eddy flux measurements and sampled every 15-30 days throughout 2011 to 2016. Separation of leaves, branches, male flowers (catkins) and acorns was performed on the collected litter. Additionally, in six trees, budburst time and individual leaf dimension were measured in a sampled branch per tree (selected in the south facing side of the canopy) to determine the start and duration of the leaf growth period. Tree leaf area index (LAI) was 
calculated using leaf biomass from litter fall and species-specific leaf area (SLA) following Costa-e-Silva et al., (2015). Maximum LAI was assumed to be coincident with the end of new leaf growth in that year and was determined by the sum of the area of all leaves shed after that date and belonging to the leaf cohort of that year. Tree height, tree diameter, and crown cover were estimated by measuring the diameter, height and crown projected area of all trees in a representative plot of 40-m radius (December 2014).

Considering the average annual biomass production of leaves, acorns, catkins and cork at our site, and each tissue mineral composition, the amount of nutrients present per tissue was estimated and compared. The average annual (2011-2016) dry weight biomass production of leaves, acorns and catkins were, respectively, $2.78 \pm 0.2,0.52 \pm 0.15$ and $0.13 \pm 0.02 \mathrm{Mg} \mathrm{ha}^{-1}$. For nutrient content determinations we used the mineral composition of each litter fall component

\subsection{Trunk gas exchanges} analyzer (LCPro+; ADC BioScientific Ltd., Hoddesdon, UK) coupled with an adapted soil chamber. All 6 trees per treatment, were measured in the morning $(0900-1100 \mathrm{~h})$ and in the afternoon (1500 -1700 h) at the same north facing side trunk azimuth. In 2014, measurements were done in the cork stripping day (July 7) and then 1, 4, 8, 17, 28 and 59 days after cork removal. In 2015, measurements were done in the cork stripping day (June 30) and then 1, 3, $8,14,35$ and 65 days after cork removal. 


\subsection{Tree leaf water potentials}

Leaf water potential was measured at predawn $\left(\Psi_{\mathrm{pd}}\right.$, a surrogate of soil water potential near roots) and midday $\left(\Psi_{\mathrm{md}}\right)$ with a Scholander-type pressure chamber (PMS Instruments, Corvallis, OR, US) in the six trees per treatment. In each tree one fully developed sun-exposed leaf was sampled at the same south facing side of the crown. Measurements were done before the cork stripping day (June 19 and June 18 in 2014 and 2015, respectively) and in the same days as indicated for trunk gas exchanges.

\subsection{Sap flow}

Sap flow was continuously measured in the 12 sampled $Q$. suber trees by the Granier method (Granier, 1985) from early June to the end of September of both years. One sensor per tree (UP $\mathrm{GmbH}$, Landshut, Germany) was radially inserted in the south-facing xylem. Each sensor consists of a pair of 2-cm-long probes inserted in the tree stem at breast height, $15 \mathrm{~cm}$ apart vertically. The upper probe was heated by a constant current, whereas the lower probe was unheated and remained at trunk temperature. In each tree sensors were insulated from radiation through an aluminium foil covering. Sensors were connected to CR23X and CR1000 data loggers (Campbell Scientific, Inc., Logan, UT, US), scanning temperature differences between probes $(\Delta T)$ every $10 \mathrm{~s}$ and recording 30-min means. Power supply was provided by car batteries and solar panel (SOP10, Solarex, Maryland, USA). Sap flux density $\left(J_{\mathrm{s}}\right)$ was calculated from 30-min values and the absolute maximum temperature difference between probes $\left(\Delta T_{\max }\right)$ over variable periods, according to night time $\Delta T$ trends and vapor pressure deficit (VPD).

From the end of July to the end of September of 2014 the radial profile of $J_{\mathrm{s}}$ at four depths below the cambium $(0.5,1,1.5$ and $2 \mathrm{~cm})$, was measured by the Compensation Heat 
Pulse (CHP) method (Green et al., 2003) in three trees per treatment. One set of heat-pulse probes (Tranzflo NZ Ltd., Palmerston North, NZ) was installed in the south-facing xylem of each tree at breast height. Two temperature probes were installed $10 \mathrm{~mm}$ downstream and 5 $\mathrm{mm}$ upstream of the heater probe, that released a heat pulse $(60 \mathrm{~J} ; 60 \mathrm{~W}$ over $1 \mathrm{~s})$ once every 30 min. Data was recorded in two CR10X data loggers (Campbell Scientific, Inc., Logan, UT, US). Sapwood fractions of water and wood were measured on cores taken from four measured trees. Comparisons of sap flow data from the Granier and the CHP methods showed that although the radial distribution of sap flow density was non-uniform over the conductive area, the Granier method provided a good estimate for the average $J_{\mathrm{s}}$ over the entire conductive area (significant correlations with $R^{2}$ between $0.81-0.89$, data not shown). Tree sap flow $(F)$ was determined as the product of $J_{\mathrm{s}}$ (obtained by the Granier method) and the sapwood conductive area. The sapwood conductive thickness was estimated considering that only the outer $32 \%$ of the trunk radius of $Q$. suber is conductive (David et al., 2007). Estimated hydroactive xylem thickness in the sampled trees ranged from 3.4 to $6.2 \mathrm{~cm}$, which always exceeded the Granier probe length.

No relation was found between $J_{\mathrm{s}}$ and tree size (e.g. diameter, crown projected area) confirming that the sampling of $J_{\mathrm{s}}$ does not need to be done for particular size classes as was also shown by Schmidt et al. (2009) for $Q$. suber. Because only one sensor was installed per tree, errors may have arisen from neglecting circumferential sap flux variability. However, because an evenly distributed circumferential sap flux density is frequently assumed for diffuse-porous species (David et al., 2007) and because the sampling and calculation procedures were the same in all trees, any errors will tend to have been systematic and should not affect our comparative analyses of the relative variation of tree sap flow in time or between treatments. 
241 Closed-system portable chambers of $15 \mathrm{~cm} \mathrm{x} 15 \mathrm{~cm}$ and $40 \mathrm{~cm}$ high connected to an Infrared 242 gas analyzer (LI-840A, LI-COR Inc., Lincoln, NE, USA) were used to measure $\mathrm{CO}_{2}$ exchanges 243 on selected sun-exposed one-year-old branches from the south-side crown of the sampled trees.

244 A transparent chamber (light chamber) measured net branch $\mathrm{CO}_{2}$ exchange $\left(F_{\text {nbe }}\right)$ and an opaque chamber (dark chamber) measured branch respiration $\left(F_{\mathrm{br}}\right)$. Branch carbon uptake $\left(F_{\mathrm{a}}\right)$ was determined by the difference between $F_{\text {nbe }}$ and $F_{\text {br. }}$ Details on the closed-system portable chambers construction and measurements are reported in Correia et al. (2014).

At the end of the experiment period all leaves from each selected branch (one branch per tree) were collected and leaf area determined (WinRhizo; Regent Instruments Inc., Quebec,

Canada). Branch carbon uptake is expressed in $\mu \mathrm{mol} \mathrm{CO}_{2} \mathrm{~m}^{-2} \mathrm{~s}^{-1}$ normalized to branch leaf area. Incident light levels on each branch were monitored using a $P A R$ quantum light sensor (QSO-S; Decagon Devices Inc., Pullman, WA, US) at the beginning and at the end of each measurement. Because $F_{\text {a }}$ is very sensitive to incident light levels variability and in order to compare trees, we determined branch light use efficiency (LUEb) as $F_{\mathrm{a}} / \mathrm{PAR}$ expressed in $\mu \mathrm{mol} \mathrm{CO} 2 \mu \mathrm{mol}^{-1}$. Measurements were conducted in four trees per treatment throughout the summer of both years, before and after cork stripping, in the same days as indicated for leaf water potential.

\subsection{Ecosystem flux measurements}

The fluxes of $\mathrm{CO}_{2}$, water vapor and sensible heat were continuously measured $(23.5 \mathrm{~m}$ above ground) by an eddy-covariance system installed at the top of a $22 \mathrm{~m}$ high tower. The system consisted of a 3-D sonic anemometer (R3; Gill Instruments Ltd., Lymington, UK) and a closedpath infrared gas analyzer (LI-7000; LI-COR Inc., Lincoln, NE, US), measuring temperature, 
the three components of wind velocity, and the concentration of water vapor and $\mathrm{CO}_{2}$. The inlet tube of the gas analyzer $(8 \mathrm{~m}$ long) was attached to one of the anemometer arms and operated with an average flow rate of ca. $8 \mathrm{~L} \mathrm{~min}^{-1}$. The reference cell is flushed with $\mathrm{N}_{2}$, and $\mathrm{CO}_{2}$ and $\mathrm{H}_{2} \mathrm{O}$ calibrations are done every 15 days. Data were continuously acquired on a field laptop with EddyMeas (Meteotools, Jena, Germany; Kolle and Rebmann, 2007).

Eddy flux data was treated using the eddy-covariance data processing software package EddyPro (v6.2.0; LI-COR Inc., Lincoln, NE, US). Fluxes were determined on a half-hourly basis by block-averaging the $20 \mathrm{~Hz}$ data. Time lags compensation was performed by automatic time lag optimization and for water vapor as a function of relative humidity (Ibrom et al., 2007). Compensation of density fluctuations was applied to raw concentration data according to Ibrom et al., (2007) although including the pressure-induced fluctuations terms. Spectral corrections of low and high-pass filtering effects were done following Ibrom et al., (2007) and Moncrieff et al., (2004), respectively. The sectorial planar fit method was used for the coordinate rotation of wind vectors (Wilczak et al., 2001). moving point test (Papale et al., 2006). All quality control tests were summed up in a simplified flag system for every half-hourly flux value according to Mauder and Foken (2011). Gap filling and flux-partitioning methods proposed by Reichstein et al. (2005) were used to fill data gaps and to separate the net ecosystem exchange (NEE) into gross primary productivity (GPP) and ecosystem respiration (Reco). Determination of net primary productivity (NPP) was done according to:

where $R_{a}$ is ecosystem autotrophic respiration and $R_{h}$ is heterotrophic soil respiration. We assumed that $\mathrm{R}_{\mathrm{h}}$ is approximately $60 \%$ of $\mathrm{R}_{\mathrm{eco}}$ based on reported values for a cork oak site in 
similar Mediterranean edapho-climatic conditions (Unger et al., 2009) and considering that soil

290

291

292

293

294

295

296

297

298

299

300

301

302

303

304

305

306

307

308

309

310

311

\section{6}

respiration is relatively consistent among Mediterranean ecosystems (Correia et al., 2012). The

NPP of the cork oak trees in the ecosystem was determined through the reduction of the shrub layer productivity (17\% of GPP) measured in closed chambers during 2011 and upscaled to the ecosystem level (Correia et al., 2014). The herbaceous vegetation was considered to have a negligent effect on the annual carbon balance based on data from an undercanopy eddyflux tower established at the same site (Piayda et al., 2014).

\subsection{Data and statistical analysis}

Summer drought stress and cork stripping effects on net carbon ecosystem exchange (NEE) were assessed by comparison of daily NEE throughout the experimental period in 2014 and 2015. To compare NEE between different periods we used only data from days without rain, with similar PAR conditions $\left(60.7 \pm 2.2 \mathrm{~mol} \mathrm{~m}^{-2} \mathrm{~d}^{-1}\right)$, using only original and high quality nightgapfilled data.

To examine differences between variables (e.g., leaf water potential, LUEb, daily NEE) we used one-way ANOVA. When ANOVA assumptions where not met, namely normal distribution of the data and homogeneity of variances, non-parametric Kruskal-Wallis test was carried out. Analysis were performed using STATISTICA (Version 7, StatSoft, Inc., 2004).

\section{Results}

\subsection{Climatic conditions}

Rainfall during the study period was quite contrasting. The year 2014 was fairly wet with a hydrological annual rainfall of $924 \mathrm{~mm}, 45 \%$ higher than local average (638 mm). Conversely, 2015 was dry with an annual rainfall of $440 \mathrm{~mm}, 31 \%$ lower than average (Fig. 1a). In 
particular, 2015 had a low winter rainfall $(86 \mathrm{~mm})$, and spring rainfall was $63 \%$ lower than in 2014 (54 vs. $147 \mathrm{~mm}$, respectively, Table 1).

SWC shown high values until April. However, from April to June, SWC was lower in 2015 than in 2014 (Fig. 1b). In the months of July and August, SWC at 40-cm depth was low in both years (6 to 4\%). In September 2014 SWC increased noticeably upon soil rewetting with autumn rains, contrasting to 2015 .

Although 2015 was a dry year, its daily maximum vapor pressure deficit (VPDmax)

320 during the summer was lower than local average (Fig. 2). Thus, in 2015, with exception for

321 June, the low VPD somehow attenuated the drought effect of the summer period. Similarly, in

3222014 the VPDmax during all summer was noticeably lower than local average, with the lowest values recorded in the 10-years dataset.

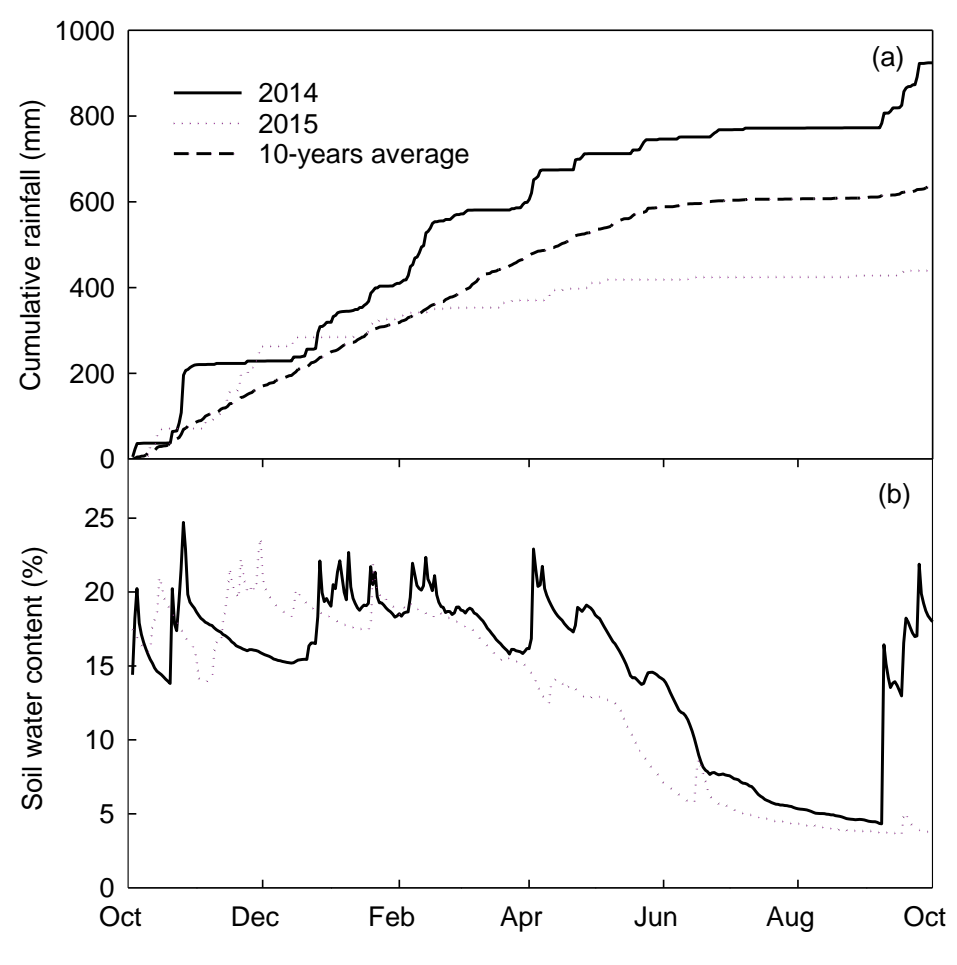


Fig. 1. (a) Cumulative rainfall (mm) during the hydrological years of 2014 and 2015 and the 10-years local average. (b) Daily values of volumetric soil water content (\%) at $40 \mathrm{~cm}$ depth during 2014 and 2015.

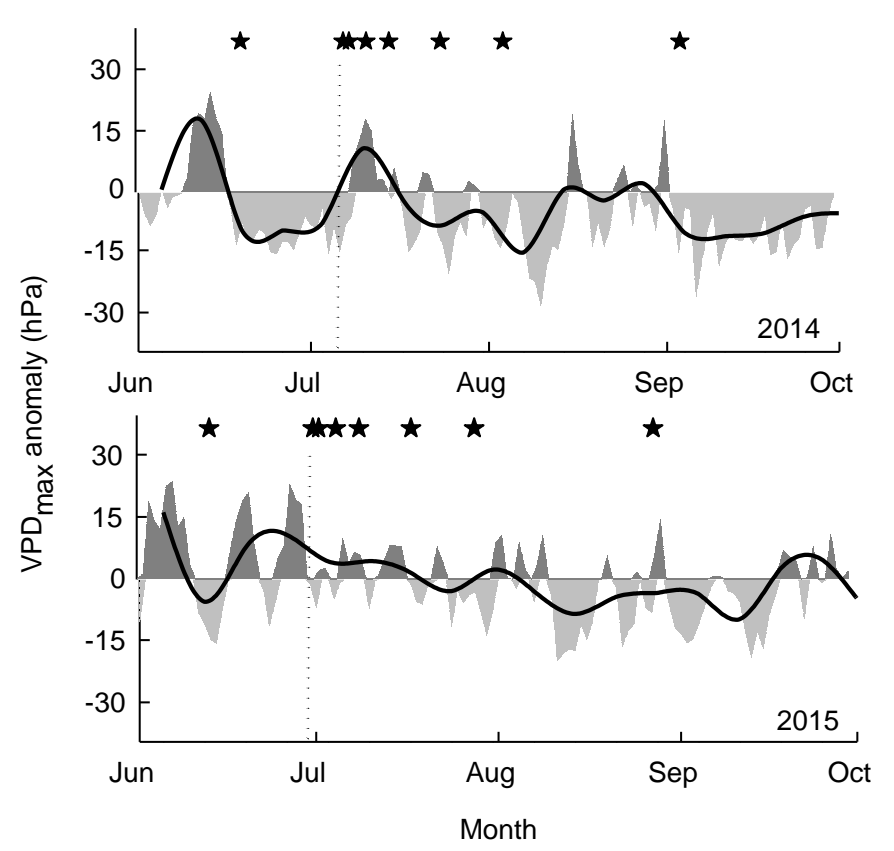

Fig. 2. Daily maximum vapor pressure deficit $\left(\mathrm{VPD}_{\max }, \mathrm{hPa}\right)$ anomalies in relation to local 10years average, during 2014 and 2015. The black line stands for a 7-day running average. Asterisks $(*)$ indicate measurement days $\left(\Psi_{\mathrm{w}}, \mathrm{LUEb}\right)$ and the dotted line the days of the cork stripping treatment in 2014 and 2015 (July 7 and June 30, respectively).

Considering the average annual nutrient investment in canopy renewal it is noticeable that reproductive structures represent a significant nutrient investment (Table 3). Particularly, primary macronutrients content in acorns represent a high investment ranging from 15.9 to 44.5 $\%$ in $\mathrm{N}$ and $\mathrm{K}$ compared to nutrient content in leaves. In contrast, primary macronutrients content in cork removed by harvesting range from 1.4 to $2.9 \%$ in $\mathrm{P}$ and $\mathrm{K}$, respectively, which represents a low investment compared to reproductive structures or leaf canopy. Considering 
the macronutrients $\mathrm{Ca}$ and $\mathrm{Mg}$, they represent a low nutrient investment both in reproductive structures or cork compared to leaf canopy.

343 Table 3. Annual nutrient content $\left(\mathrm{kg} \mathrm{ha}^{-1} \mathrm{year}^{-1}\right)$ of each litter fall component and of cork 344 removed in harvesting. Values are means $\pm s e(n=6)$.

\begin{tabular}{lcccc}
\hline & Leaves & Acorns $^{\mathrm{a}}$ & Catkins $^{\mathrm{a}}$ & Cork $^{\mathrm{a}}$ \\
$\mathrm{N}$ & $28.9 \pm 1.8$ & $4.6 \pm 1.4(15.9)$ & $2.4 \pm 0.3(8.4)$ & $0.55(1.9)$ \\
$\mathrm{P}$ & $2.5 \pm 0.2$ & $0.7 \pm 0.2(29.1)$ & $0.3 \pm 0.04(12.8)$ & $0.04(1.4)$ \\
$\mathrm{K}$ & $11.7 \pm 0.7$ & $5.2 \pm 1.5(44.5)$ & $2.2 \pm 0.3(18.6)$ & $0.33(2.9)$ \\
$\mathrm{Ca}$ & $16.1 \pm 1.0$ & $0.4 \pm 0.1(2.3)$ & $0.2 \pm 0.02(1)$ & $0.9(5.6)$ \\
$\mathrm{Mg}$ & $6.1 \pm 0.4$ & $0.5 \pm 0.2(8.5)$ & $0.3 \pm 0.04(5)$ & $0.04(0.6)$
\end{tabular}

${ }^{a}$ numbers between brackets are percentage of tissue nutrients in relation to leaves nutrient content

\subsection{Trunk gas exchanges}

The pattern of trunk water loss and trunk respiration after cork stripping was similar in 2014 and 2015 (Fig. 3). Maximum trunk water loss occurred in the cork stripping day in 2015 and four days after cork stripping in 2014 (Fig. 3a) coincident with a VPD peak (43.3 hPa, Fig. 2).

Trunk evaporation decreased linearly thereafter until a minimum was reached, 60 days after cork stripping, similar to the values of control trees which were always close to zero in both years (on average $1.6 \pm 0.9 \mu \mathrm{mol} \mathrm{H} 2 \mathrm{O} \mathrm{m}^{-2} \mathrm{~s}^{-1}$ ). Considering the days of maximum trunk water loss in 2014 and 2015 and the respective cork stripped area per tree (Table 2) the maximum flux of water loss was on average $19.1 \pm 1.6 \mathrm{~g} \mathrm{H}_{2} \mathrm{O} \mathrm{h}^{-1}$ tree $^{-1}$. 
minimum in the next 10 days (Fig. 3b). One month after cork stripping trunk respiration slightly increased and maintained the same rates until the end of the experiment.

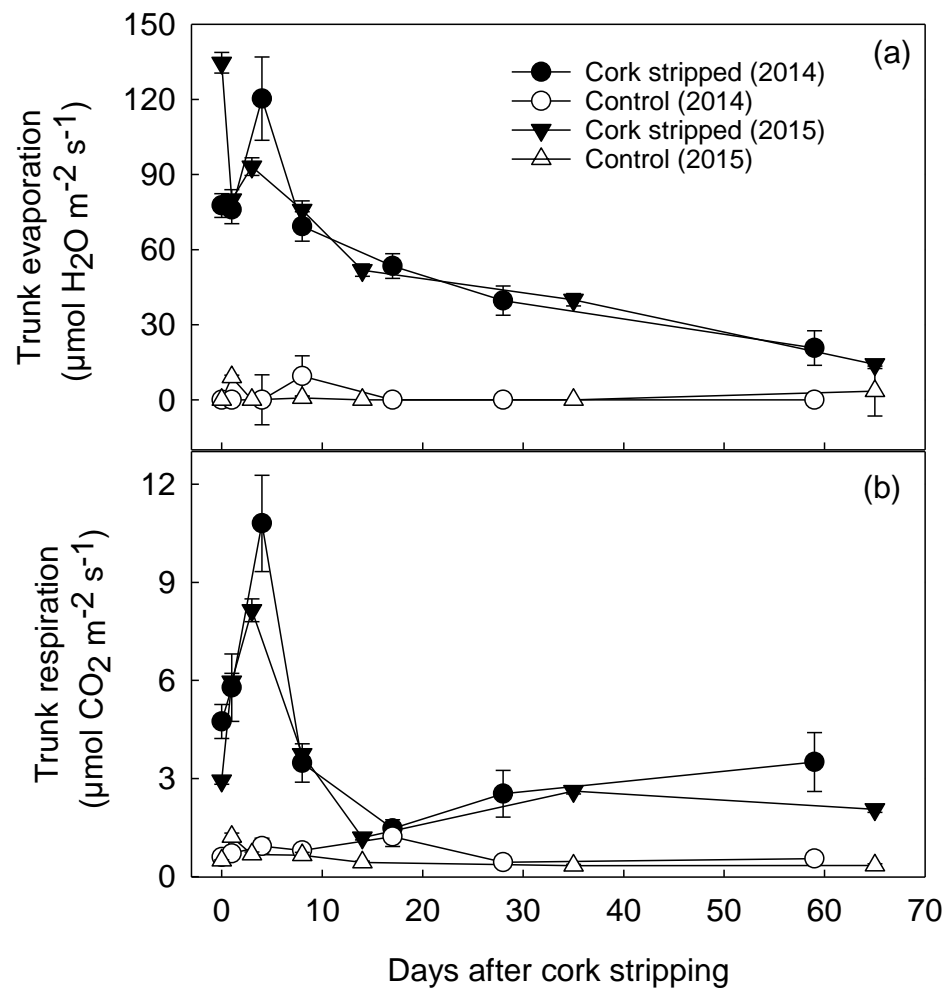

360

361 Fig. 3. Trunk gas exchanges measured in control and cork stripped trees during the study 362 period. Cork stripping treatment was done on July 7 and June 30 in 2014 and 2015, 363 respectively. (a) Trunk evaporation $\left(\mu \mathrm{mol} \mathrm{H}_{2} \mathrm{O} \mathrm{m}^{-2} \mathrm{~s}^{-1}\right)$. (b) Trunk respiration $\left(\mu \mathrm{mol} \mathrm{CO} 2 \mathrm{~m}^{-2} \mathrm{~s}^{-}\right.$

$\left.{ }^{1}\right)$. Values are means \pm se $(n=6)$.

Tree leaf water potential measured throughout the summer of 2014 indicated no signs of water deficits in both treatments: $\Psi_{\mathrm{pd}}$ remained always higher than $-0.3 \mathrm{MPa}$ (Fig. 4) confirming a high soil water availability. In this same year, $\Psi_{\mathrm{md}}$ values were low in both treatments with a decrease on days 4 and 8 after cork stripping in response to the high VPD. In 2015, there were 
also no significant differences in $\Psi_{\mathrm{pd}}$ between both treatments along the summer although more

372

373

374

375

376

377

378

negative $\Psi_{\mathrm{pd}}$ were reached in the peak of summer stress (early September), 65 days after treatment cork stripping (-0.7 MPa, on average). On the other hand, in 2015 there were significant differences between treatments in $\Psi_{\mathrm{md}}$. Cork stripped trees showed higher $\Psi_{\mathrm{md}}$ than control trees, particularly from 3 to 14 days after cork stripping, suggesting higher stomatal closure in this treatment. In late summer of 2015, 65 days after treatment cork stripping, the smaller difference between $\Psi_{\mathrm{pd}}$ and $\Psi_{\mathrm{md}}$ shows that water stress had developed in both treatments.

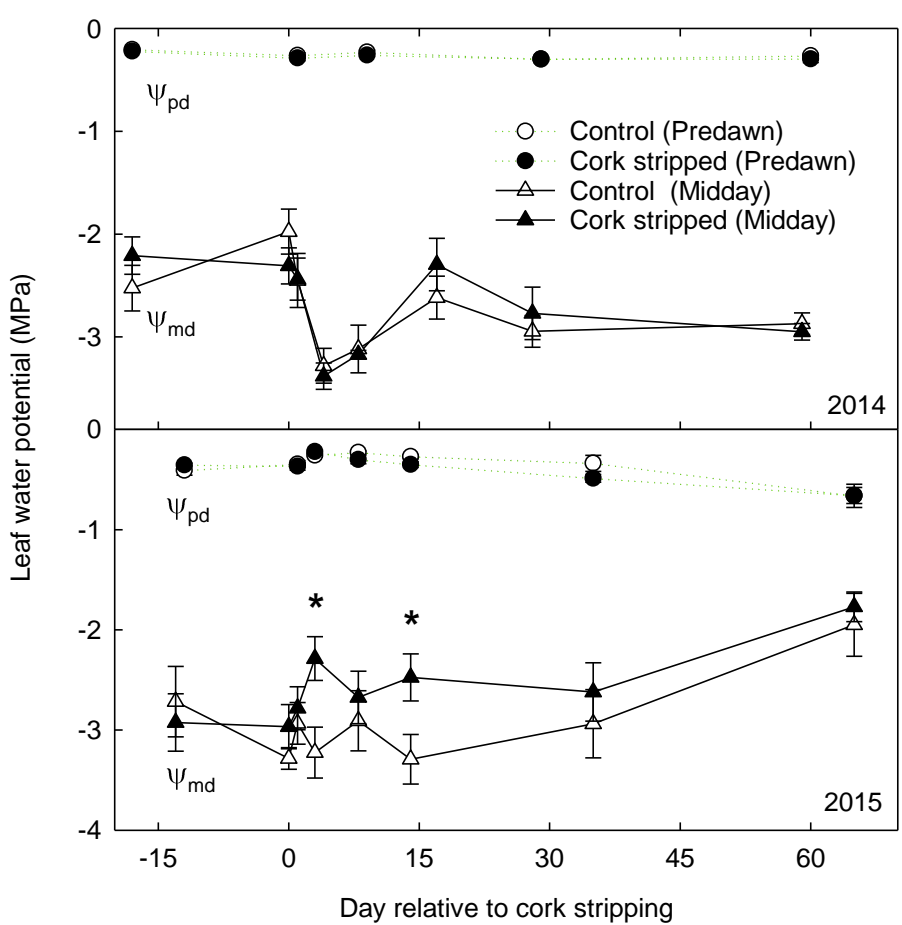

380

Fig. 4. Predawn $\left(\Psi_{\mathrm{pd}}\right)$ and midday $\left(\Psi_{\mathrm{md}}\right)$ tree leaf water potential $(\mathrm{MPa})$ measured in control and cork stripped trees during the study period. The cork stripping treatment was done on July 7 and June 30 in 2014 and 2015, respectively. Values are means \pm se $(n=6)$. Asterisks $\left(^{*}\right)$ represent statistical significant differences at $\mathrm{P}<0.05$. 
386 During the study period of 2014 the patterns of tree sap flow $(F)$ were similar for both 387 treatments (Fig. 5). High daily $F$, above $100 \mathrm{~L} \mathrm{tree}^{-1}$ day $^{-1}$, were maintained until the end of 388 August (45 days after cork stripping) indicating that there were no restrictions on soil water availability. At the end of the dry season, following the first autumn rains in early September (60 days after cork stripping), maximum daily $F$ decreased on average $20 \%$ in relation to the maximum seasonal $F$ showing that a lower evaporative demand (lower radiation and VPD (see Fig. 2)) was limiting $F$ rather than soil water availability. In 2015, during the first 30 days of the study period, before the cork stripping treatment, maximum daily $F$ showed a 2 -fold decrease in relation to the same period of 2014 as a result of the reduced water availability. After cork stripping, trees showed an immediate $20 \%$ reduction in $F$ compared to control trees, and this difference increased progressively up to 55\% after 30 days. On average cork stripped trees showed a $46 \%$ decrease in $F$ during the dry season of 2015 compared to control trees. Furthermore, both treatments responded differently to drought along the dry season: control trees maintained high $F$ during July (0-30 days after treatment) and decreased maximum $F, 13$ and 31\% in August (30-60 days after treatment) and September (60-90 days after treatment), respectively, whereas cork stripped trees decreased 19,57 and 56\% maximum $F$ in July, August and September, respectively. 


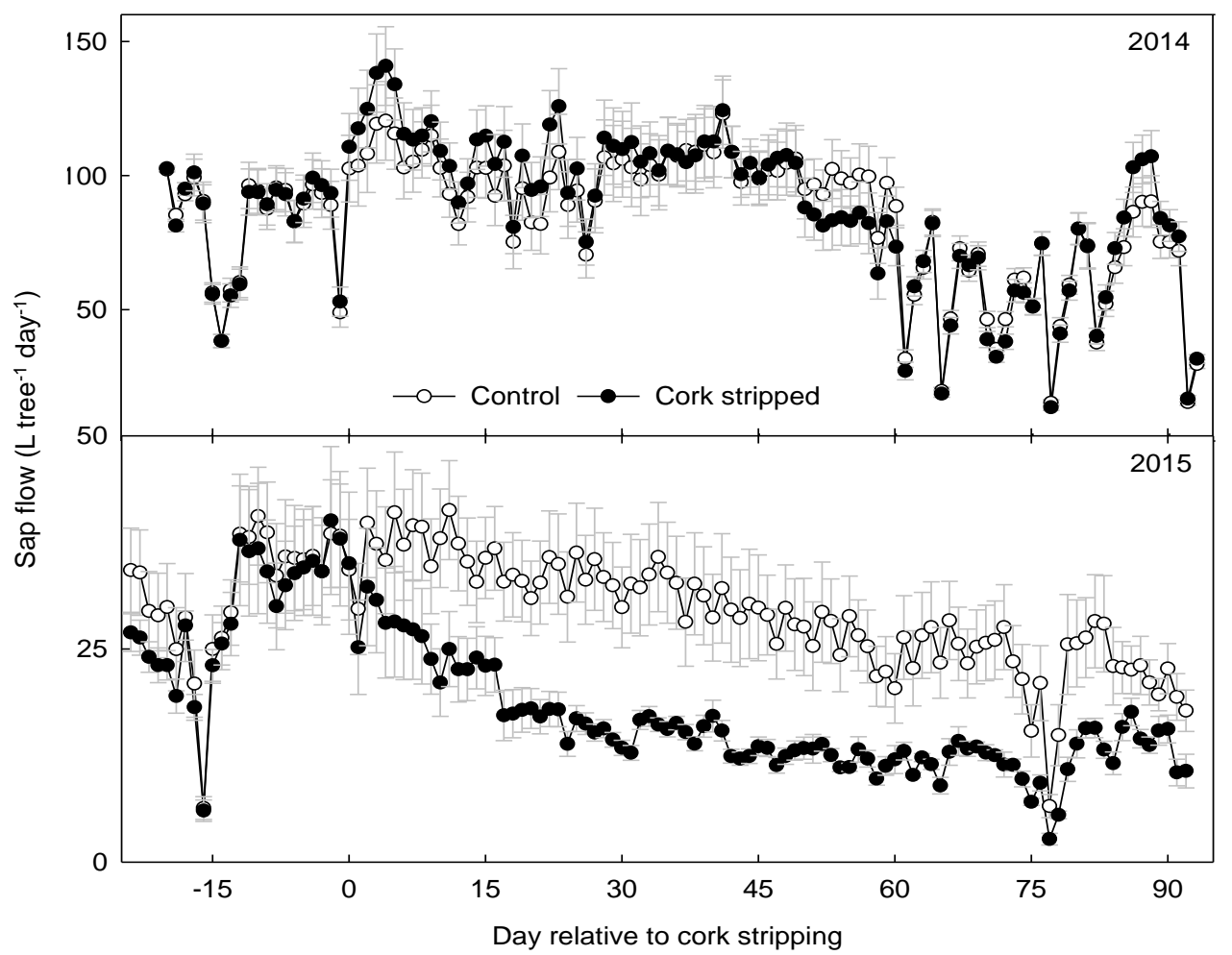

403

Fig. 5. Sap flow ( tree $^{-1}$ day $\left.^{-1}\right)$ determined for control and cork stripped trees during the study 405 period. The cork stripping treatment was done on July 7 and June 30 in 2014 and 2015, 406 respectively. Values are means \pm se $(n=6)$.

407

408

\subsection{Branch light use efficiency}

The main interannual differences and treatment variation in LUEb can be perceived in Fig. 6 .

During 2014, LUEb showed no differences between treatments across the dry season with a high variability between trees as a result of the high patchiness in incident PAR. In comparison to $2014, \mathrm{LUE}_{\mathrm{b}}$ decreased on average $50 \%$ in $2015(0.028 \pm 0.015$ vs. $0.014 \pm 0.004 \mu \mathrm{mol} \mathrm{CO} 2$ $\mu \mathrm{mol}^{-1}$, respectively). In the first 35 days after cork stripping in 2015, LUE$_{\mathrm{b}}$ showed an average $50 \%$ reduction in cork stripped trees compared to control trees. In addition, during the dry season $\mathrm{LUE}_{b}$ of cork stripped trees showed a higher decrease than control trees in relation to the maximum seasonal LUEb (76 and 55\%, respectively). 


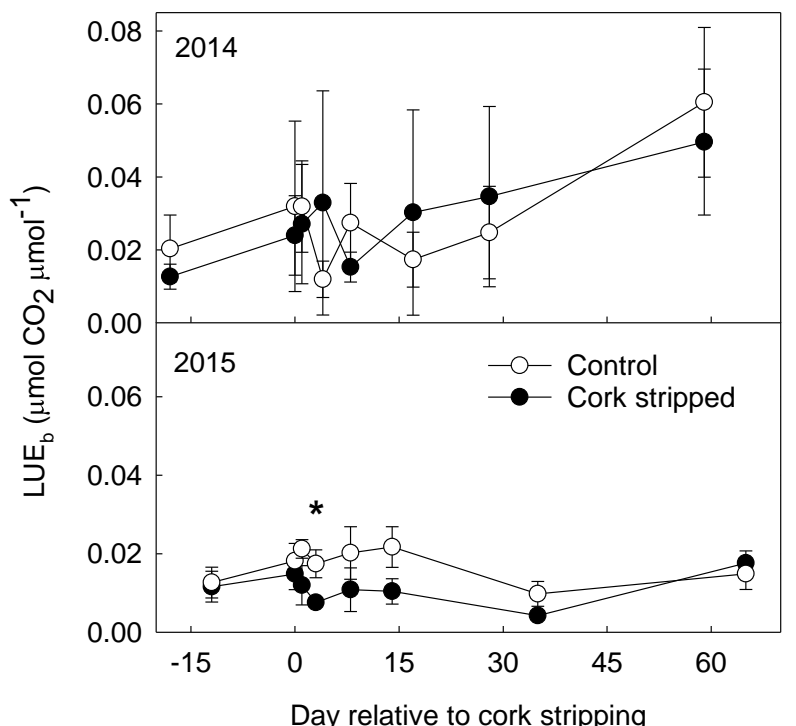

417

Day relative to cork stripping

418 Fig. 6. Branch light use efficiency $\left(\mathrm{LUE}_{\mathrm{b}}\right)$ measured in 1-year old branches of control and cork stripped trees during the study period. The cork stripping treatment was done on July 7 and June 30 in 2014 and 2015, respectively. Values are means \pm se $(n=4)$. Asterisks $(*)$ represent statistical significant differences at $\mathrm{P}<0.05$.

\subsection{Ecosystem $\mathrm{CO}_{2}$ uptake}

424 It is important to consider that in 2015 , June 11 to 13 , all trees in the cork oak woodland were cork harvested with the exception of the 12 experimental trees (see section on Tree sampling, Methods). Cumulative net ecosystem $\mathrm{CO}_{2}$ exchange (NEE) clearly showed the effect of low rainfall and cork stripping in 2015 by reducing carbon sequestration: after cork stripping till the end of September absolute $\mathrm{CO}_{2}$ uptake decreased 59\%, from -246 in 2014 to $-101 \mathrm{~g} \mathrm{C} \mathrm{m}^{-2}$ in 2015 (Fig. 7a). However, before cork harvesting, from May to early June 2015, there was already a 39\% lower carbon uptake in relation to 2014 (-47 vs. $-77 \mathrm{~g} \mathrm{C} \mathrm{m}^{-2}$, respectively), which can be ascribed to the lower water availability as also reflected by the concomitant lower sap

432 flow rates in the same period (Fig. 5). In addition, the maximum daily carbon uptake in early 433 June was also significantly higher in 2014 than in 2015 (-5.4 vs. $-3.3 \mathrm{~g} \mathrm{C} \mathrm{m}^{-2}$ day $^{-1}$, Fig. 7b). In 
the first 10 days after cork harvesting in 2015 NEE decreased $73 \%$ in relation to the June period before cork stripping. After the third week in June till the middle of July, NEE partially recovered being 38\% lower than in early June (Fig. 7b and Fig. 8). While in 2014 high absolute

437 values of carbon sequestration were maintained till the end of July to subsequently decrease 438 steeply until the end of summer, in the dry 2015 the decrease in NEE occurs gradually after middle of July (Fig. 7b). In both years with the onset of autumn rains (6 and 15 September in 2014 and 2015, respectively), NEE decreases abruptly as a consequence of soil rehydration years (Fig. $7 \mathrm{a}$ and $\mathrm{b})$.

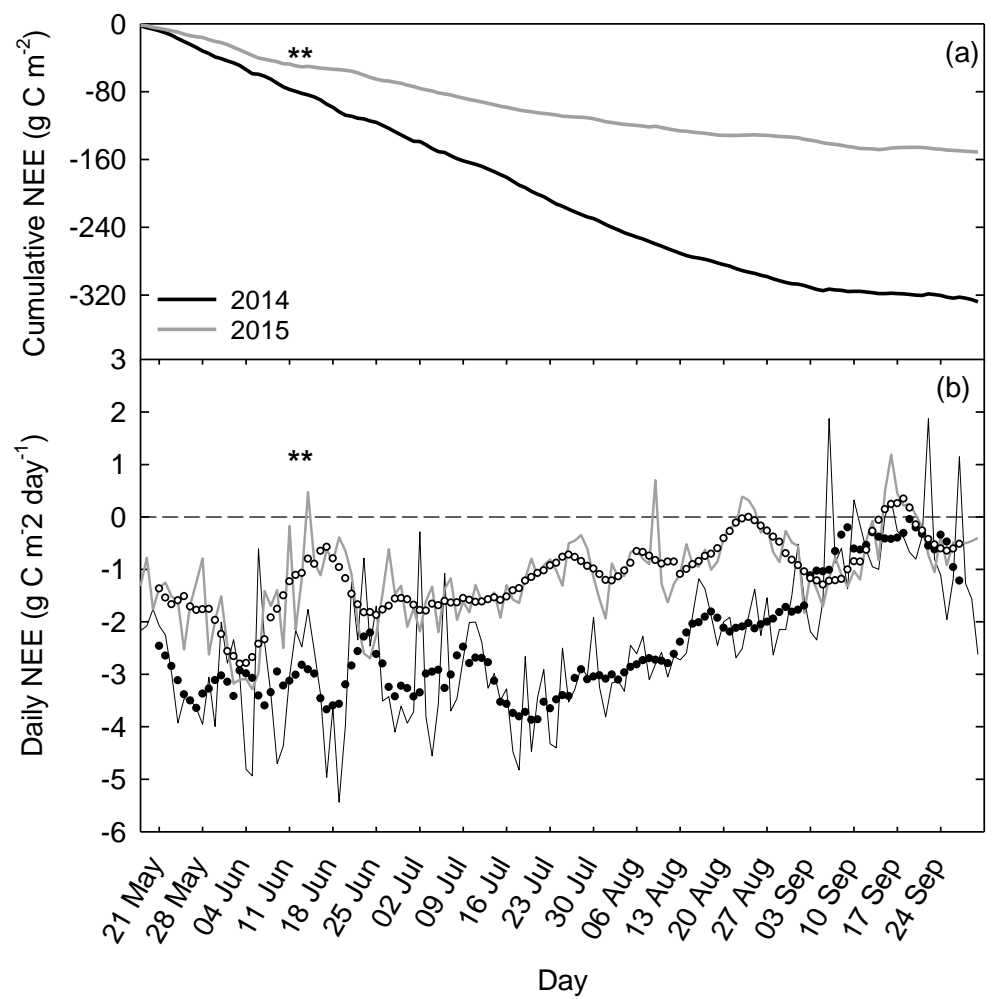

443

$$
\text { Day }
$$

444 Fig. 7. Cumulative (a) and daily values (b) of net carbon ecosystem exchange (NEE) during 2014 and 2015. The black and open circles in panel (b) stands for a 7-day running average. 

harvesting in 2015 (11-13 June).

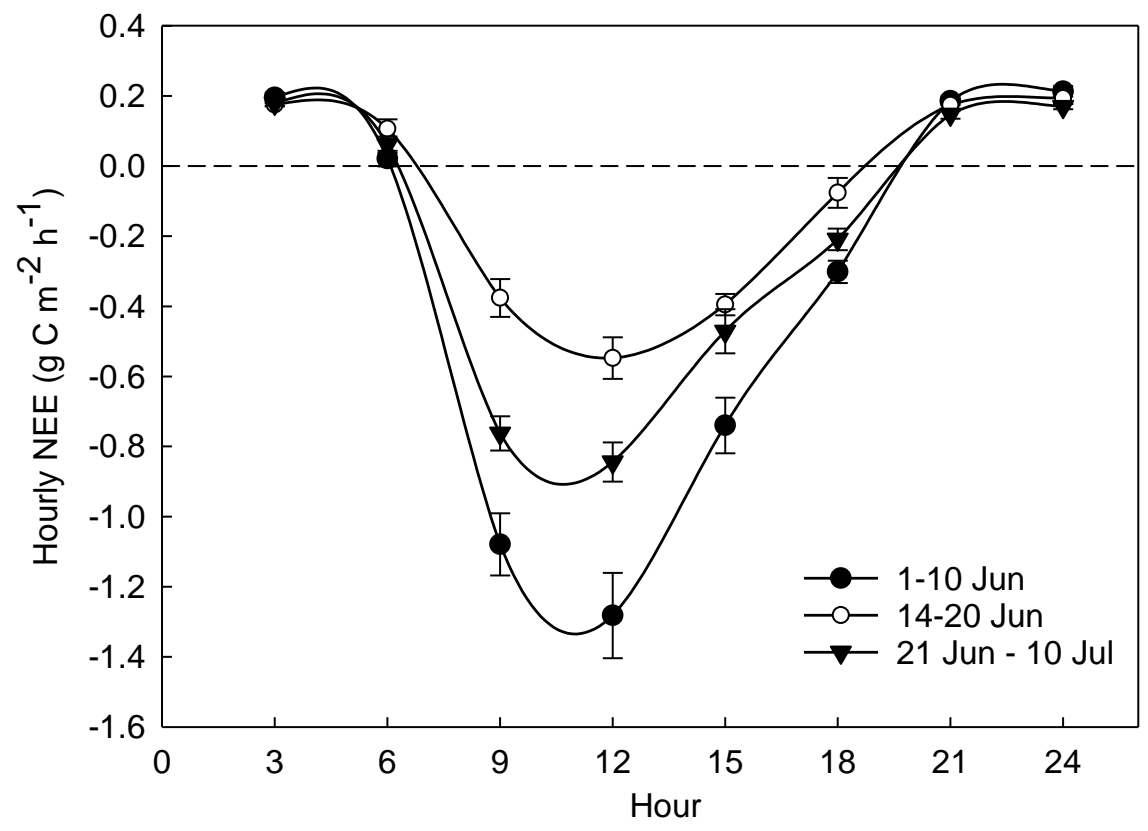

449

Fig. 8. Hourly mean values of net carbon ecosystem exchange (NEE) determined for three periods before and after site cork stripping in 2015 (11-13 June). Negative values represent carbon sequestration in the ecosystem while positive values represent carbon emissions to the atmosphere.

\section{Discussion}

\subsection{Effects of cork stripping on tree carbon and nutrient balance}

457 In the Mediterranean hot dry-summer region, cork oak woodland ecosystems are major reserves for terrestrial carbon and a major component of regional primary productivity. Anthropogenic influences, such as management, land degradation, or overexploitation impact on carbon emissions and sequestration of cork oak woodlands. Cork harvesting implies direct carbon losses for the tree and the ecosystem. We have determined that the amount of carbon 
harvested on a yearly basis relative to the net primary productivity (NPP) of cork oak trees was is a minor component of the tree carbon balance, only marginally affecting its energy balance driven by photosynthate production. Therefore, cork harvest barely affects the ecosystem carbon balance, and ecosystem carbon sequestration should be credited as an asset in cork production as it was envisaged by Vallejo et al. (2009).

Cork oak is a mast-cropping tree which generally occupies low resource environments and, therefore, is prone to show a marked decline in carbon reserves and vegetative growth following a high reproductive investment (Chapin et al., 1990). It has been suggested that cork stripping and new cork growth may be compared to the investment in flowers and fruits, which do not contribute to carbon assimilation and compete with other tree components for nutrients and photoassimilates (Oliveira and Costa, 2012).

Our results show that cork is a very low resource demanding tissue, as reflected by its low carbon costs in relation to the tree NPP and low nutrient content. In fact, primary macronutrients content in cork amounts to approximately $2 \%$ of the yearly nutrient needs of the leaf canopy and represents much lower needs than those of fruits and flowers (Table 3). Furthermore, following cork stripping it was not observed any significant decrease on reproductive growth either on 2015 (acorn production) or 2016 (acorn and catkins production) (data not shown). Likewise, the allocation of assimilated carbon and/or of stored carbon to regenerate the cork layer did not affect the new leaf development in 2016 as the ecosystem maximum leaf area index has slightly increased (1.9). However, it is well known that cork stripping has a major effect on tree radial growth, particularly in cork growth. As early as in 1938, it was observed that after cork stripping the activity of the vascular cambium decreases and the wood growth stops (Natividade 1938). Leal et al. (2008) estimated that cork stripping led to an annual reduction of wood growth (ring width) of approximately 57\% in the first 2 
years after cork regeneration even under favorable water availability conditions. Conversely, after stripping, cork growth shows a marked increment in the first year that can reach 2 to 3 times the thickness of previous annual periods (Costa and Oliveira, 2001; Costa et al., 2003). Therefore, although cork represents a low carbon and nutrient store as compared to leaf canopy or reproductive structures, phellogen sink strength is considerably enhanced after cork stripping resulting in a cork growth increase. This suggests that sink strength relations between the phellogen and the vascular cambium are significantly altered after cork stripping at least during the first 2 years, resulting in a decrease of wood growth.

Source-sink activity is controlled by a complex signaling network involving both physical and chemical signals that play an important role in communicating sink demand and regulating partitioning (Smith et al., 2018; Körner, 2015). Phellogen activity and subsequent cork cells growth was found to be a highly effective sink for photoassimilated carbon (Aguado et al., 2012, 2017). These authors have shown that suberin, the main cork cell wall component, was the major carbon sink for the carbon assimilated throughout the whole active growth period, i.e. from early spring to late autumn, as compared to other stem chemical components. This can partially explain differences in tree components growth and the underlined resource allocation competition. Furthermore, considering that carbon assimilates fluxes greatly depend on the source-sink distances (Lacointe, 1999), its plausible to admit a decrease in root growth as observed for wood growth during the first two years after cork stripping. This may have a crucial role in lowering the tree resilience capacity facing abiotic (e.g. sequential drought episodes) and biotic stresses (e.g. Phythoptora cinnamomi) which greatly depend on the root system capacity to maintain a favourable tree water balance (David et al., 2016).

Bark thickness determines the distance of external factors to vital meristemic tissues (cambium, buds), phloem and the xylem. Major functions of the outer bark (cork) include reduction of water loss, barring against pathogen entry, protection against mechanical injury, 
insulation of the stem against adverse climatic conditions and protection against wildfire. There is increasing evidence that having a thick bark increases fitness in many fire-prone ecosystems (Pausas, 2015). Therefore, from an evolutionary pressure perspective a transference priority in carbon assimilates allocated to the growth of new cork after stripping is justified by the important role of cork in the cork oak ecological fitness.

\subsection{Effects of cork stripping on tree water balance}

519 Cork stripping leaves the innermost conducting tissues - phloem and xylem - exposed to the external environment and tree stems have no immediate mechanism to control water loss from these tissues. This water loss is very perceptible in the wet trunks after cork stripping although it was only rarely quantified. Some rough estimates suggested that this daily water loss could equal that of leaf transpiration (Oliveira and Costa, 2012; Correia et al., 1992). Our measurements clearly show that this trunk water loss is negligible in comparison to canopy transpiration (Fig. 3 and 5). Considering an average cork stripped area per tree, the maximum flux of water loss was on average $19.1 \pm 1.6 \mathrm{~g} \mathrm{H}_{2} \mathrm{O} \mathrm{h}^{-1}$ tree $^{-1}$. This maximum stem water evaporation value represents approximately $2 \%$ of the canopy transpiration rate for the same daily period. Thus, the quantity of water evaporating from the stripped surfaces does not imply a significant effort by the tree to maintain water balance throughout the dry summer period. demand (VPD) only in the first days after cork stripping. After this initial period trunk evaporation decreases linearly until reaching a minimum 60 days after cork stripping, similar to control trees (Fig.3). Upon cork stripping, the exposed outermost phloem cells dry out and die and form an early (yet not fully effective) protective layer which covers the inner living tissues. The decrease of stem water loss, to values similar to control trees, seems to indicate 
that only after 60 days the scar tissues and the first new layers of the regenerating periderm are

537 fully insulating. This suggests that the rate of $\mathrm{CO}_{2}$ and $\mathrm{H}_{2} \mathrm{O}$ diffusion from the stem to the air is effectively limited with the cell tissue reconstruction of phellogen (traumatic phellogen) that initiates approximately after 25-35 days (Machado, 1944).

Monitoring tree sap flow has allowed us to assess the effect of cork stripping on canopy transpiration during the summer of 2014 and 2015 (Fig. 5). Tree response to cork stripping varied with soil water availability: in 2014 (wet year) canopy transpiration was similar between control and cork stripped trees, whereas in 2015 (dry year) cork stripping led to a significant reduction in transpiration through stomatal closure as supported by the increase in midday leaf water potential in treatment trees (Fig. 4). In 2015 with an annual precipitation 31\% lower than the local average, cork stripping led to a $46 \%$ reduction of canopy transpiration in comparison to control trees. The literature has reported variable effects of cork stripping on $\mathrm{g}_{\mathrm{s}}$, ranging from small reductions not limiting photosynthesis (Werner and Correia, 1996) to different responses according to trees (Correia et al., 1992). In addition, tree water status, as reflected by $\Psi_{\mathrm{w}}$, did not change considerably in stripped cork oaks (Correia et al., 1992; Werner and Correia, 1996). All these results and our own differences between the wet and dry year, strongly suggest that stripping effects on $\mathrm{g}_{\mathrm{s}}$ are triggered by an interaction between stripping traumatic effects and environmental effects as soil water availability decreases.

Cork stripping, in terms of tree physiological effects can be regarded as a traumatic wounding with similarities to stem girdling (e.g. De Schepper et al., 2010; Lopéz et al., 2015). Though unlike girdling, the phloem tissue remains in the tree and only the periderm is removed with cork stripping. We can then expect a disruption of the basipetal movement of assimilates through phloem where a new traumatic phellogen will be formed within the deeper nonconducting phloem tissues (Oliveira and Costa 2012). We have observed a significant lower sucrose content in the trunk phloem tissue of cork stripped trees compared to leaf tissues and 
to an accumulation in control trees (data not shown), suggesting a disruption and impairment of phloem components transport.

Soon after site cork harvesting in 2015 there was a clear reduction in NEE which was maintained until the end of summer, representing a 59\% NEE decrease in relation to the same period of 2014 (Fig. 7a). This NEE decrease was due to a combined effect of cork stripping and summer water stress induced by a lower water availability. The $50 \%$ reduction in Branch Light Use Efficiency from 2015 to 2014 (Fig. 6) confirms the effects of these stresses on carbon assimilation metabolism. Although these two stress effects on NEE are difficult to disentangle, from May to early June, before entire site cork harvesting, there was already a 39\% lower carbon uptake in 2015 in relation to 2014, which can be solely attributed to the lower soil water availability. This cause-effect association in this period is evidenced by the concomitant $60 \%$ lower sapflow rates in 2015 compared to 2014 (Fig. 5). However, it is worth mentioning that in 2015, from cork stripping days to middle of July, control trees (not cork stripped) maintained stable sapflow rates (Fig. 5). Considering the well-known trade-off of water for carbon (e.g. Sperry et al., 2017), this clearly indicates that the observed decrease in NEE in this period, when all ecosystem trees were cork harvested, should not be ascribed to the dry season progressive decline in soil water availability but only to the effect of cork stripping. Therefore, we can reliably estimate the cork stripping effect on NEE in this period. Cork stripping stress effects were particularly significant in a short-term phase of approximately 10 days which led to a NEE decline of $73 \%$ in relation to the June period before cork stripping. After this short period NEE partially recovered until middle of July being $38 \%$ lower than the initial June NEE values (Fig. 8). This cork stripping induced decline on ecosystem carbon uptake can be 
estimated as a reduction of $41.6 \mathrm{~g} \mathrm{C} \mathrm{m}^{-2}$, which correspond to $16 \%$ of the yearly NEE or $32 \%$

586

587

of total summer (June-September) carbon sequestration. After this period and until the onset of autumn rains the ecosystem productivity decreased progressively (Fig. 7b) due to a severe reduction in water availability. In fact, we can suggest that in this late summer period, the decrease in NEE in comparison to 2014 can be ascribed predominantly to the effects of soil water deficits. This is supported by the same magnitude values of carbon sequestration exhibited for July and August in a similar dry year (2012 with 420 mm precipitation), with a NEE of -66 vs. $-61 \mathrm{~g} \mathrm{C} \mathrm{m}^{-2}$ in 2012 and 2015, respectively (Costa e Silva et al., 2015).

\section{Conclusions}

In summary, the effects of cork oak bark stripping in tree water and carbon fluxes were clearly shown here for the first time. We have demonstrated that cork is a very low demanding tissue as reflected by its low carbon costs in relation to the tree NPP (1.5\% on a yearly basis) and low nutrient content. Additionally, our results clearly show that the quantity of water evaporating from the stripped stem surfaces is not significant in terms of summer tree water balance: $c a$. $2 \%$ in comparison to canopy transpiration. Cork stripping induced an increase in midday leaf water potential and a decrease (46\%) on sap flow in the dry year. This suggests that stripping may trigger an enhanced stomatal closure through an interaction between stripping traumatic effects and soil water scarcity. Although the drought stress effects on carbon sequestration are more prominent than the cork stripping ones, this superimposed stress led to a significant reduction of early summer carbon uptake (ca. 32\% of summer NEE in 2015) in a period of maximum physiological tree activity. A lower quantity of available photoassimilates can have a (difficult to estimate) detrimental effect on vital growth metabolism, storage of carbon reserves and production of biochemical defence compounds. These effects can be especially 
609

610

611

612

613

614

615

616

617

618

619

620

621

622

623

624

625

626

627

628

629

630

critical to more vulnerable trees, growing near their vitality breakdown threshold. Regarding cork oak woodland management and considering the effects of cork stripping on tree physiology, this forest practice should be avoided in severe dry years and in the more stressprone trees. The present work adds novel insights on how ecosystem carbon sequestration and tree water balance are affected by cork harvesting.

\section{Acknowledgements}

The authors wish to thank António Gonçalves Ferreira and Alfredo Gonçalves Ferreira for providing field site facilities at Machoqueira do Grou, and Grupo Amorim for the continuous support in the eddy-flux tower maintenance. This research was funded by the Forest Research Centre, a research unit funded by Fundação para a Ciência e a Tecnologia I.P. (FCT), Portugal (UIDB/00239/2020). A. C. Correia was funded by the grant number SFRH/BPD/108858/2015. We also thank J. S. Pereira for bringing new perspectives and excellent suggestions to this research.

\section{References}

Aguado, P.L., Curt, M.D., Pereira, H. and Fernandez, J., 2012. Allocation of C-14 assimilated in late spring to tissue and biochemical stem components of cork oak (Quercus suber L.) over the seasons. Tree Physiology, 32(3): 313-325. DOI: 10.1093/treephys/tps012

Aguado, P.L., Curt, M.D., Pereira, H. and Fernández, J., 2017. The influence of season on carbon allocation to suberin and other stem components of cork oak saplings. Tree Physiology, 37(2): 165-172. DOI: 10.1093/treephys/tpw116 
Aronson, J., Pereira, J.S. and Pausas, J., 2009. Cork oak woodlands on the edge: ecology, biogeography, and restoration of an ancient Mediterranean ecosystem. Island Press, Washington, DC.

Bugalho, M.N., Caldeira, M.C., Pereira, J.S., Aronson, J. and Pausas, J.G., 2011. Mediterranean cork oak savannas require human use to sustain biodiversity and ecosystem services. Frontiers in Ecology and the Environment, 9(5): 278-286. DOI: $10.1890 / 100084$

Chapin III, F.S., Schulze, E. and Mooney, H.A., 1990. The Ecology and Economics of Storage in Plants. Annual Review of Ecology and Systematics, 21(1): 423-447. DOI: 10.1146/annurev.es.21.110190.002231

Correia, A.C. et al., 2014. Carbon sink strength of a Mediterranean cork oak understorey: how do semi-deciduous and evergreen shrubs face summer drought? Journal of Vegetation Science, 25(2): 411-426. DOI: 10.1111/jvs.12102

Correia, A.C. et al., 2012. Soil water availability strongly modulates soil CO2 efflux in different Mediterranean ecosystems: models calibration using the Bayesian approach. Agriculture, Ecosystems \& Environment, 161: 88-100. DOI: 10.1016/j.agee.2012.07.025

Correia, O.A., Oliveira, G., Martins-Loução, M.A. and Catarino, F.M., 1992. Effects of bark stripping on the water relations of Quercus suber L. Scientia gerundensis, 18: 195-204.

Costa, A. and Oliveira, A.C., 2001. Variation in cork production of the cork oak between two consecutive cork harvests. Forestry, 74(4): 337-346. DOI: 10.1093/forestry/74.4.337

Costa, A., Pereira, H. and Oliveira, A., 2003. Variability of radial growth in cork oak adult trees under cork production. Forest Ecology and Management, 175(1-3): 239-246. DOI: 10.1016/s0378-1127(02)00145-7 
655 Costa, A., Pereira, H. and Oliveira, A., 2004. The effect of cork-stripping damages on diameter 656 growth of Quercus suber L. . Forestry, 77(1): 1-8. DOI: 10.1093/forestry/77.1.1

657

658

659

660

661

662

663

664

665

666

667

668

669

670

671

672

673

674

675

676

677

678

Costa e Silva, F. et al., 2015. Effects of an extremely dry winter on net ecosystem carbon exchange and tree phenology at a cork oak woodland. Agricultural and Forest Meteorology, 204: 48-57. DOI: 10.1016/j.agrformet.2015.01.017

David, T.S. et al., 2012. Hydraulic connectivity from roots to branches depicted through sap flow: analysis on a Quercus suber tree. Functional Plant Biology, 39(2): 103-115. DOI: $10.1071 / \mathrm{fp} 11185$

David, T.S., Ferreira, M.I., Cohen, S., Pereira, J.S. and David, J.S., 2004. Constraints on transpiration from an evergreen oak tree in southern Portugal. Agricultural and Forest Meteorology, 122(3-4): 193-205. DOI: 10.1016/j.agrformet.2003.09.014

David, T.S. et al., 2007. Water-use strategies in two co-occurring Mediterranean evergreen oaks: surviving the summer drought. Tree Physiology, 27(6): 793-803. DOI: 10.1093/treephys/27.6.793

David, T.S., Pinto, C.A., Nadezhdina, N. and David, J.S. 2016. Water and forests in the Mediterranean hot climate zone: a review based on a hydraulic interpretation of tree functioning. Forest Systems 25(2), eR02. 14p. DOI: 10.5424/fs/2016252-08899

De Schepper, V., Steppe, K., Van Labeke, M.C. and Lemeur, R., 2010. Detailed analysis of double girdling effects on stem diameter variations and sap flow in young oak trees. Environmental and Experimental Botany, 68(2): 149-156. DOI: 10.1016/j.envexpbot.2009.11.012

Domingues, V., 2005. Utilização de um produto natural (cortiça) como adsorvente de pesticidas piretróides em águas. Phd Thesis, Faculdade de Engenharia da Universidade do Porto. 
679 Evangelista, M., 2010. Relatório da caracterizacão da fileira florestal 2010. Associação para a

680

681

682

683

684

685

686

687

688

689

690

691

692

693

694

695

696

697

698

699

700

701 competitividade da indústria da fileira florestal, Portugal, $80 \mathrm{pp}$.

Gil, L., Pereira, C. and Silva, P., 2005. Cork and CO2 fixation. In: U.d. Huelva (Editor), Suberwood: New challenges for integration of cork oak forests and products, Huelva.

Granier, A., 1985. A new method of sap flow measurement in tree stems. Annales Des Sciences Forestieres, 42(2): 193-200. DOI: 10.1051/forest:19850204

Green, S.R., Clothier, B.E. and Jardine, B., 2003. Theory and practical application of heatpulse to measure sap flow. Agronomy Journal, 95(6): 1371-1379. DOI: 10.2134/agronj2003.1371

Ibrom, A., Dellwik, E., Larsen, S.E. and Pilegaard, K., 2007. On the use of the webb pearmanleuning theory for closed-path eddy correlation measurements. Tellus B, 59(5): 937946. DOI: 10.1111/j.1600-0889.2007.00311.x

Kolle, O. and Rebmann, C., 2007. Eddysoft - documentation of a software package to acquire and process eddy-covariance data. Technical Reports. Max-Planck-Institute for Biogeochemistry 10, Jena, DE.

Körner, C., 2015. Paradigm shift in plant growth control. Current Opinion in Plant Biology, 25: 107-114. DOI: 10.1016/j.pbi.2015.05.003

Kurz-Besson, C. et al., 2006. Hydraulic lift in cork oak trees in a savannah-type Mediterranean ecosystem and its contribution to the local water balance. Plant and Soil, 282(1-2): 361378. DOI: $10.1007 / \mathrm{s} 11104-006-0005-4$

Lacointe, A., 2000. Carbon allocation among tree organs: A review of basic processes and representation in functional-structural tree models. Annals of Forest Science, 57(5): 521-533. DOI: 10.1051/forest:2000139 
Leal, S., Nunes, E. and Pereira, H., 2008. Cork oak (Quercus suber L.) wood growth and vessel characteristics variations in relation to climate and cork harvesting. European Journal of Forest Research, 127(1): 33-41. DOI: 10.1007/s10342-007-0180-8

López, R., Brossa, R., Gil, L. and Pita, P., 2015. Stem girdling evidences a trade-off between cambial activity and sprouting and dramatically reduces plant transpiration due to feedback inhibition of photosynthesis and hormone signaling. Frontiers in Plant Science, 6(285). DOI: 10.3389/fpls.2015.00285

Machado, D.P., 1944. A intensidade do crescimento da cortiça e melhoramento da sua qualidade nas sucessivas despelas. Boletim da Junta Nacional da Cortiça, 74: 57-58.

Mauder, M. and Foken, T., 2011. Documentation and Instruction Manual of the EddyCovariance Software Package TK3. Universitt Bayreuth Abt. , Mikrometeorologie.

Moncrieff, J.B., Clement, R., Finnigan, J. and Meyers, T., 2004. Averaging, Detrending, and Filtering of Eddy Covariance Time Series. In: X. Lee, W. Massman and B. Law (Editors), Handbook of Micrometeorology. Springer, Dordrecht, Atmospheric and Oceanographic Sciences Library, pp. 7-31. DOI: 10.1007/1-4020-2265-4_2

Natividade, J.V., 1938. Técnica cultural dos sobreirais II - Descortiçamento. Junta Nacional da Cortiça, Lisboa.

Oliveira, G., Correia, O., Martins-Loução, M. and Catarino, F.M., 1994. Phenological and growth-patterns of the Mediterranean oak Quercus suber L. Trees-Structure and Function, 9(1): 41-46.

Oliveira, G. and Costa, A., 2012. How resilient is Quercus suber L. to cork harvesting? A review and identification of knowledge gaps. Forest Ecology and Management, 270: 257-272. DOI: 10.1016/j.foreco.2012.01.025 
Oliveira, G., Martins-Loução, M.A., Correia, O. and Catarino, F.M., 1996. Nutrient dynamics in crown tissues of cork-oak (Quercus suber L.). Trees, 10: 247-254. DOI: 10.1007/BF02185676

Papale, D. et al., 2006. Towards a standardized processing of Net Ecosystem Exchange measured with eddy covariance technique: algorithms and uncertainty estimation. Biogeosciences, 3(4): 571-583. DOI: 10.5194/bg-3-571-2006

Pausas, J.G., 2005. Bark thickness and fire regime. Functional Ecology, 29(3): 315-327. DOI: $10.1111 / 1365-2435.12372$

Pereira, H., 2007. Cork: Biology, Production and Uses. Elsevier Science B.V., Amsterdam, 346 pp. DOI: 10.1016/B978-044452967-1/50007-8

Pereira, J.S., Kurz-Besson, C. and Chaves, M.M., 2009. Coping with drought. Part II. Scientific Bases for restoration and management. In: J. Aronson, J.S. Pereira and J.G. Pausas (Editors), Cork oak woodlands on the edge: ecology, adaptive management, and restoration. Island Press, Washington, DC, pp. 73-80.

Piayda, A. et al., 2014. Drought impact on carbon and water cycling in a Mediterranean Quercus suber L. woodland during the extreme drought event in 2012. Biogeosciences, 11(24): 7159-7178. DOI: $10.5194 / \mathrm{bg}-11-7159-2014$

Pinto, C.A. et al., 2011. Phenology and growth dynamics in Mediterranean evergreen oaks: Effects of environmental conditions and water relations. Forest Ecology and Management, 262(3): 500-508. DOI: 10.1016/j.foreco.2011.04.018

Reichstein, M. et al., 2005. On the separation of net ecosystem exchange into assimilation and ecosystem respiration: review and improved algorithm. Global Change Biology, 11(9): 1424-1439. DOI: 10.1111/j.1365-2486.2005.001002.x

Schmidt, M.W.T. et al., 2009. Sap Flow in Cork Oak Trees at Two Contrasting Sites in Portugal. Acta horticulturae, 846: 345-352. DOI: 10.17660/ActaHortic.2009.846.40 
Smith, M.R., Rao, I.M. and Andrew, M., 2018. Source-Sink Relationships in Crop Plants and Their Influence on Yield Development and Nutritional Quality. Frontiers in Plant Science, 9(1889). DOI: 10.3389/fpls.2018.01889

Sperry, J.S., Venturas, M.D., Anderegg, W.R.L., Mencuccini, M., Mackay, D.S., Wang, Y., Love, D.M., 2017. Predicting stomatal responses to the environment from the optimization of photosynthetic gain and hydraulic cost. Plant Cell Environ. 40, 816830. https://doi.org/10.1111/pce.12852.

Unger, S. et al., 2009. Partitioning carbon fluxes in a Mediterranean oak forest to disentangle changes in ecosystem sink strength during drought. Agricultural and Forest Meteorology, 149(6-7): 949-961. DOI: 10.1016/j.agrformet.2008.11.013

Vallejo, V.R., Aronson, J., Pausas, J.G., Pereira, J.S. and Fontaine, C., 2009. The Way Forward. In: J. Aronson, J.S. Pereira and J.G. Pausas (Editors), Cork Oak Woodlands on the Edge: Ecology, Adaptive Management, and Restoration. Island Press, Washington DC, pp. 235-245.

Vaz, M. et al., 2010. Drought-induced photosynthetic inhibition and autumn recovery in two Mediterranean oak species (Quercus ilex and Quercus suber). Tree Physiology, 30(8): 946-956. DOI: 10.1093/treephys/tpq044

Vickers, D. and Mahrt, L., 1997. Quality Control and Flux Sampling Problems for Tower and Aircraft Data. J. Atmos. Oceanic Technol., 14: 512-526. DOI: 10.1175/15200426(1997)014<0512:QCAFSP>2.0.CO;2

Werner, C. and Correia, O., 1996. Photoinhibition in cork-oak leaves under stress: Influence of the bark-stripping on the chlorophyll fluorescence emission in Quercus suber L. Trees-Structure and Function, 10(5): 288-292. DOI: 10.1007/BF02340774 
773 Wilczak, J.M., Oncley, S.P. and Stage, S.A., 2001. Sonic anemometer tilt correction algorithms. Boundary-Layer Meteorology, 99(1): 127-150. DOI: 10.1023/a:1018966204465 